\title{
Widespread air pollutants of the North China Plain during the Asian summer monsoon season: a case study
}

\author{
Jiarui Wu ${ }^{1,3}$, Naifang Bei ${ }^{2}, \mathrm{Xia} \mathrm{Li}^{1,3}$, Junji Cao ${ }^{1}$, Tian Feng ${ }^{1}$, Yichen Wang ${ }^{1}$, Xuexi Tie ${ }^{1}$, and Guohui $\mathrm{Li}^{1}$ \\ ${ }^{1}$ Key Lab of Aerosol Chemistry and Physics, SKLLQG, Institute of Earth Environment, Chinese Academy of Sciences, \\ Xi'an, China \\ ${ }^{2}$ School of Human Settlements and Civil Engineering, Xi'an Jiaotong University, Xi' an, Shaanxi, China \\ ${ }^{3}$ University of Chinese Academy of Science, Beijing, China
}

Correspondence: Guohui Li (ligh@ieecas.cn) and Junji Cao (jjcao@ieecas.cn)

Received: 15 December 2017 - Discussion started: 8 January 2018

Revised: 16 May 2018 - Accepted: 18 May 2018 - Published: 18 June 2018

\begin{abstract}
During the Asian summer monsoon season, prevailing southeasterly-southwesterly winds are subject to delivering air pollutants from the North China Plain (NCP) to northeast and northwest China. In the present study, the WRF-CHEM model is used to evaluate contributions of trans-boundary transport of NCP emissions to the air quality in northeast and northwest China during a persistent air pollution episode from 22 to 28 May 2015. The WRF-CHEM model generally performs well in capturing the observed temporal variation and spatial distribution of fine particulate matter $\left(\mathrm{PM}_{2.5}\right)$, ozone $\left(\mathrm{O}_{3}\right)$, and $\mathrm{NO}_{2}$. The simulated temporal variation of aerosol species is also in good agreement with measurements in Beijing during the episode. Model simulations show that NCP emissions contribute substantially to the $\mathrm{PM}_{2.5}$ level in Liaoning and Shanxi provinces, the adjacent downwind areas of the NCP, with an average of 24.2 and $13.9 \mu \mathrm{g} \mathrm{m}^{-3}$ during the episode, respectively. The $\mathrm{PM}_{2.5}$ contributions in Jilin and Shaanxi provinces are also appreciable, with an average of 9.6 and $6.5 \mu \mathrm{g} \mathrm{m}^{-3}$, respectively. The average percentage contributions of NCP emissions to the $\mathrm{PM}_{2.5}$ level in Liaoning, Jilin, Shanxi, and Shaanxi provinces are 40.6, 27.5, 32.2, and $20.9 \%$, respectively. The NCP emissions contribute remarkably to the $\mathrm{O}_{3}$ level in Liaoning province, with an average of $46.5 \mu \mathrm{g} \mathrm{m}^{-3}$, varying from 23.9 to $69.5 \mu \mathrm{g} \mathrm{m}^{-3}$. The $\mathrm{O}_{3}$ level in Shanxi province is also influenced considerably by NCP emissions, with an average contribution of $35.1 \mu \mathrm{g} \mathrm{m}^{-3}$. The $\mathrm{O}_{3}$ level in Shanxi province is also influenced considerably by NCP emissions, with an average contribution of $35.1 \mu \mathrm{g} \mathrm{m}^{-3}$. The average $\mathrm{O}_{3}$ contributions of NCP emissions to Jilin and Shaanxi provinces
\end{abstract}

are 28.7 and $20.7 \mu \mathrm{g} \mathrm{m}^{-3}$, respectively. The average percentage contributions of NCP emissions to the afternoon $\mathrm{O}_{3}$ level in Liaoning, Jilin, Shanxi, and Shaanxi provinces are 27.4, $19.5,21.2$, and $15.8 \%$, respectively. However, the effect of NCP emissions on the air quality in Inner Mongolia is generally insignificant. Therefore, effective mitigation of NCP emissions not only improves the local air quality, but is also beneficial to the air quality in northeast and northwest China during the Asian summer monsoon season.

\section{Introduction}

With the rapid growth of industrialization, urbanization, and transportation, China has recently experienced severe air pollution with high levels of fine particulate matter $\left(\mathrm{PM}_{2.5}\right)$ and ozone $\left(\mathrm{O}_{3}\right)$ (e.g., Chan and Yao, 2008; Zhang et al., 2013; Kurokawa et al., 2013; G. Li et al., 2017b). Although the Chinese State Council issued the "Atmospheric Pollution Prevention and Control Action Plan" in September 2013, with the aim of improving China's air quality, heavy haze or photochemical smog still frequently plagues China, especially in the North China Plain (NCP), Yangtze River Delta (YRD), and Pearl River Delta (PRD). Elevated $\mathrm{O}_{3}$ and $\mathrm{PM}_{2.5}$ concentrations in the atmosphere not only perturb regional and global climates, but also exert adverse effects on air quality, ecosystems, and human health (Weinhold, 2008; Parrish and Zhu, 2009).

The NCP has become one of the most polluted areas in the world due to a large amount of emissions of pollutants 
and frequent occurrence of unfavorable meteorological situations, as well as the topography (e.g., Tang et al., 2012; Zhang et al., 2013; Zhuang et al., 2014; Pu et al., 2015; Long et al., 2016). Heavy haze with extremely high $\mathrm{PM}_{2.5}$ concentrations often covers the NCP during wintertime, partially attributable to coal combustion for domestic heating (e.g., He et al., 2001; Cao et al., 2007; H. Li et al., 2017). However, even in summer, with improvement of the evacuation conditions and increase of precipitation, photochemical smog with high levels of $\mathrm{PM}_{2.5}$ and $\mathrm{O}_{3}$ still engulfs the NCP (e.g., Gao et al., 2011; Hu et al., 2014; Cao et al., 2015; Wu et al., 2017). The $\mathrm{PM}_{2.5}$ concentrations during summertime in the NCP are generally lower than those in winter, but are still much higher than $35 \mu \mathrm{g} \mathrm{m}^{-3}$, the first grade of National Ambient Air Quality Standards (NAAQS) in China (Feng et al., 2016; Z. S. Wang et al., 2016; Sun et al., 2016). The average summertime $\mathrm{PM}_{2.5}$ concentrations in the NCP are $77.0 \pm 41.9 \mu \mathrm{g} \mathrm{m}^{-3}$ in 2013 , much more than those in other regions of China and also exceeding the second grade of NAAQS (Hu et al., 2014). In addition, increasing $\mathrm{O}_{3}$ precursor emissions have caused serious $\mathrm{O}_{3}$ pollution during summertime in the NCP (e.g., Zhang et al., 2009; Xu et al., 2011; Kurokawa et al., 2013). G. Li et al. (2017b) reported that the maximum $1 \mathrm{~h} \mathrm{O}_{3}$ concentration exceeded $200 \mu \mathrm{g} \mathrm{m}{ }^{-3}$ in almost all the cities in eastern China from April to September 2015, mainly concentrated in the NCP and YRD, showing widespread and persistent $\mathrm{O}_{3}$ pollution. Ma et al. (2016) found a growth trend of surface $\mathrm{O}_{3}$ at a rural site in the NCP from 2003 to 2015, with an average rate of $1.13 \mathrm{ppb}$ per year. Wu et al. (2017) showed that the average afternoon $\mathrm{O}_{3}$ concentration in the summer of 2015 in Beijing was about $163 \mu \mathrm{g} \mathrm{m}^{-3}$.

China is located in a large monsoon domain, and the Asia summer monsoon (ASM) tends to substantially influence the distribution and trans-boundary transport of air pollutants in China. Zhu et al. (2004) have proposed that the summertime high $\mathrm{O}_{3}$ concentration over western China is due to the monsoonal transport from eastern China and long-range transport from south/central Asia and even Europe. Zhao et al. (2010) have also indicated that $\mathrm{O}_{3}$ transported from south/central Asia to western China increases from May to August because of the northward movement of the India summer monsoon. Huang et al. (2015) have suggested that an earlier onset of the ASM would lead to more $\mathrm{O}_{3}$ enhancement in the lower troposphere over the NCP in later spring and early summer. Numerous studies have also reported that the strength and temporospatial extension of the ASM influences the spatial and temporal distribution of aerosol mass concentrations over eastern China (Cao et al., 2015; Li et al., 2016; Cheng et al., 2016). For example, Zhang et al. (2010) have emphasized that the east ASM plays a major role in determining the seasonal and interannual variations of the $\mathrm{PM}_{2.5}$ concentration over eastern China. Using the GEOS-CHEM model, Zhu et al. (2012) have shown that the weakening of the ASM increases the aerosol concentration in eastern China. Wu et al. (2016) have pointed out that the regional transport and tempo-spatial distribution of air pollutants are directly influenced by the East Asian monsoon at seasonal, interannual, and decadal scales.

During the ASM season, meteorological conditions are characterized by prevailing southwesterly-southeasterly winds over eastern China. Air pollutants originated from the NCP are likely to be transported northwards and affect the air quality in its downwind areas, so it is imperative to quantitatively evaluate the effect of NCP emissions on the air quality in its neighboring regions. Previous studies have concentrated on the composition, characteristics, and sources of the air pollutants over the NCP (e.g., Han et al., 2006; Liu et al., 2012; Zhao et al., 2013; Li et al., 2015). However, few studies have been performed to investigate the effect of transboundary transport of air pollutants originated from the NCP on the air quality in northeast and northwest China under the prevailing southerly wind associated with the ASM.

In this study, we first analyze the role of synoptic situations during the ASM (from May to September) in the transboundary transport over northern China and further evaluate the contribution of trans-boundary transport of pollutants originated from the NCP to the air quality in northeast and northwest China using the WRF-CHEM model. The model configuration and methodology are described in Sect. 2. Analysis results and discussions are presented in Sect. 3, and conclusions are given in Sect. 4.

\section{Model and methodology}

\subsection{WRF-CHEM model and configuration}

A persistent air pollution episode with high levels of $\mathrm{PM}_{2.5}$ and $\mathrm{O}_{3}$ from 22 to 28 May 2015 in northern China is simulated using the WRF-CHEM model, which was developed by Li et al. (2010, 2011a, b, 2012) at the Molina Center for Energy and the Environment. Table 1 provides detailed model configurations and Fig. 1 shows the WRF-CHEM model simulation domain. It is worth noting that the horizontal resolution of $10 \mathrm{~km}$ adopted in this study is the lower bound for the WRF model to turn on the cumulus scheme, so the new Kain-Fritsch scheme is used in the present study (Table 1). Further description of the model is presented in the Supplement.

The key characteristics of the aerosol pollution in China are frequently associated with rather efficient secondary formation, including aerosol nucleation and rapid growth under favorable conditions (Zhang et al., 2012, 2015; Qiu and Zhang, 2013; Guo et al., 2014). The new particle production rate in the WRF-CHEM model is calculated due to the binary nucleation of $\mathrm{H}_{2} \mathrm{SO}_{4}$ and $\mathrm{H}_{2} \mathrm{O}$ vapor. The nucleation rate is a parameterized function of temperature, relative humidity, and the vapor-phase $\mathrm{H}_{2} \mathrm{SO}_{4}$ concentration, following the work of Kulmala et al. (1998), and the new particles are 
Table 1. WRF-CHEM model configurations.

\begin{tabular}{ll}
\hline Regions & Northern China \\
\hline Simulation period & 22 to 28 May 2015 \\
Domain size & $350 \times 350$ \\
Domain center & $35^{\circ} \mathrm{N}, 114^{\circ} \mathrm{E}$ \\
Horizontal resolution & $10 \mathrm{~km} \times 10 \mathrm{~km}$ \\
Vertical resolution & 35 vertical levels with a stretched vertical grid with spacing ranging from \\
& $30 \mathrm{~m}$ near the surface to $500 \mathrm{~m}$ at $2.5 \mathrm{~km}$ and $1 \mathrm{~km}$ above 14 km \\
Microphysics scheme & WSM 6-class graupel scheme (Hong and Lim, 2006) \\
Boundary layer scheme & MYJ TKE scheme (Janjić, 2002) \\
Surface layer scheme & MYJ surface scheme (Janjić, 2002) \\
Cumulus scheme & Kain-Fritsch (new Eta) scheme (Kain, 2004) \\
Land-surface scheme & Unified Noah land-surface model (Chen and Dudhia, 2001) \\
Longwave radiation scheme & Goddard longwave scheme (Chou and Suarez, 2001) \\
Shortwave radiation scheme & Goddard shortwave scheme (Chou and Suarez, 1999) \\
Meteorological boundary and initial conditions & NCEP $1^{\circ} \times 1^{\circ}$ reanalysis data \\
Chemical initial and boundary conditions & MOZART 6 h output (Horowitz et al., 2003) \\
Anthropogenic emission inventory & SAPRC-99 chemical mechanism emissions (Zhang et al., 2009) \\
Biogenic emission inventory & MEGAN model developed by Guenther et al. (2006) \\
Model spin-up time & 28 h \\
\hline
\end{tabular}

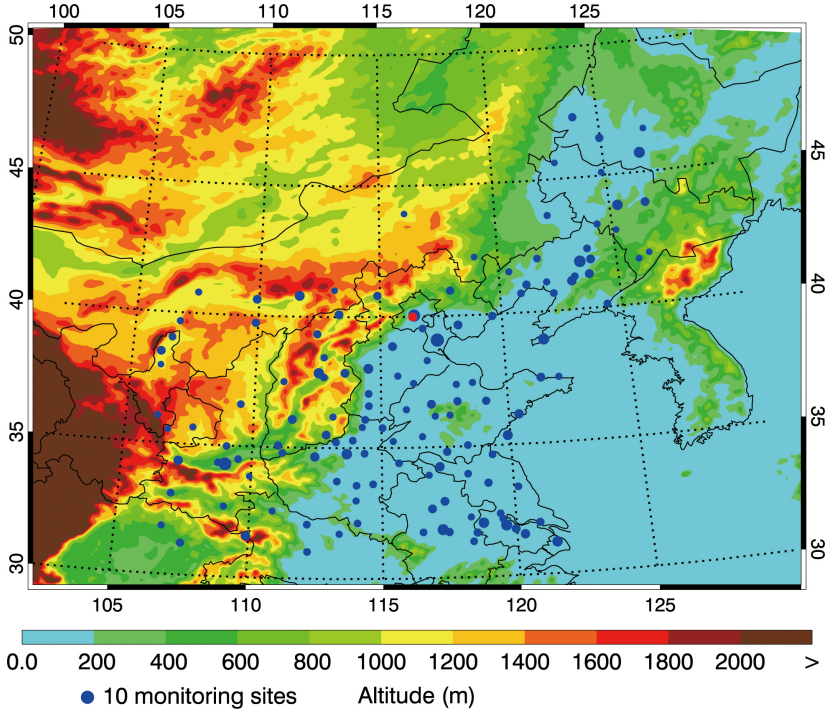

Figure 1. WRF-CHEM simulation domain with topography. The blue circles represent centers of cities with ambient monitoring sites and the red circle denotes the NCNST site. The size of the blue circle represents the number of ambient monitoring sites of cities.

assumed to have a diameter of $2.0 \mathrm{~nm}$. Recent studies have shown that organic vapors are involved in the nucleation process (Zhang et al., 2012) and further studies need to be conducted to consider the contributions of organic vapors to the nucleation process. The secondary organic aerosol (SOA) formation is simulated using a nontraditional SOA model including the volatility basis-set modeling method in which primary organic components are assumed to be semi-volatile and photochemically reactive and are distributed in logarith- mically spaced volatility bins (Li et al., 2011a). The contributions of glyoxal and methylglyoxal to the SOA formation are also included in the SOA module. The SOA formation from glyoxal and methylglyoxal is parameterized as a first-order irreversible uptake by aerosol particles, with a reactive uptake coefficient of $3.7 \times 10^{-3}$ for glyoxal and methylglyoxal (Zhao et al., 2006). The simulation of inorganic aerosols in the WRF-CHEM model adopts the ISORROPIA version 1.7 (Nenes et al., 1998).

For the discussion convenience, northern China is divided into three regions (Fig. S1 in the Supplement): (1) the North China Plain (including Beijing, Tianjin, Hebei, Shandong, Henan, and the south of Jiangsu and Anhui, hereafter referred to as the NCP), (2) northeast China (including Heilongjiang, Jilin, Liaoning, and the east part of Inner Mongolia, hereafter referred to as NEC), and (3) northwest China (including Shanxi, Shaanxi, and the west part of Inner Mongolia, hereafter referred to as NWC). During the episode, the observed average daily $\mathrm{PM}_{2.5}$ concentration was $75.5 \mu \mathrm{g} \mathrm{m}^{-3}$ and the mean $\mathrm{O}_{3}$ concentration in the afternoon was $151.2 \mu \mathrm{g} \mathrm{m}^{-3}$ in the NCP. Figure S2 presents the distributions of the anthropogenic emission rates of volatile organic compounds (VOCs), nitrogen oxide $\left(\mathrm{NO}_{x}\right)$, organic carbon (OC), and $\mathrm{SO}_{2}$ in mainland China, showing that the high emission rates of VOCs, $\mathrm{NO}_{x}, \mathrm{OC}$, and $\mathrm{SO}_{2}$ are generally concentrated in the NCP. It is worth noting that uncertainties in the emission inventory used in this study are rather large, considering the rapid changes in anthropogenic emissions that are not fully reflected in the current emission inventory and the complexity of pollutants' precursors. 


\subsection{Data and methodology}

In the present study, the model performance is validated using the hourly measurements of $\mathrm{O}_{3}, \mathrm{NO}_{2}$, and $\mathrm{PM}_{2.5}$ concentrations released by China's Ministry of Environment Protection (China MEP), which can be accessed at http://www. aqistudy.cn/ (last access: 8 June 2018). In addition, the simulated submicron sulfate, nitrate, ammonium, and organic aerosols are compared to the measurements by the Aerodyne Aerosol Chemical Speciation Monitor (ACSM), which was deployed at the National Center for Nanoscience and Technology (NCNST), Chinese Academy of Sciences in Beijing (Fig. 1). The observed mass spectra of organic aerosols are analyzed using the positive matrix factorization (PMF) technique and four components are identified: hydrocarbonlike organic aerosol (HOA), cooking organic aerosol (COA), coal combustion organic aerosol (CCOA), and oxygenated organic aerosol (OOA). HOA, COA, and CCOA are interpreted together as a surrogate of primary organic aerosols (POA), and OOA is a surrogate of secondary organic aerosols (SOA). Furthermore, the reanalysis data from the European Centre for Medium-Range Weather Forecasts (ECMWF) are used to analyze the synoptic patterns during the ASM season from May to September 2015.

The mean bias (MB), root mean square error (RMSE), and the index of agreement (IOA) are utilized to evaluate the performance of the WRF-CHEM model simulations against measurements. To assess the contributions of NCP emissions to the near-surface concentrations of $\mathrm{O}_{3}$ and $\mathrm{PM}_{2.5}$ in NEC and NWC, the factor separation approach (FSA) is used in this study (Stein and Alpert, 1993; Gabusi et al., 2008; Li et al., 2014). The detailed description of methodology can be found in Sect. S2.

\section{Results and discussion}

\subsection{Synoptic patterns during the ASM season}

The ASM prevails from May to September each year in China, with strong winds blowing from oceans to eastern China and bringing warm and moist airflow to the continent. Furthermore, the western Pacific subtropical high gradually intensifies and moves from south to north, influencing the weather and climate over China and also transporting water vapor from the sea to eastern China. During the ASM season, due to the influence of the western Pacific subtropical high, rain belts and associated deep convection move from southeastern China to northern China (Ding, 1992; Ding and Chan, 2005; Kang et al., 2002; Lau, 1992; Lau et al., 1988). Figure 2 shows the geopotential heights at $500 \mathrm{hPa}$ and mean sea level pressure with wind vectors during the ASM season in 2015. At $500 \mathrm{hPa}$, the main part of the subtropical high, which is represented by the scope of the contour of 5880 geopotential meter, is located in the northwestern $\mathrm{Pa}$ - cific Ocean. The mean ridgeline of the western Pacific subtropical high is located at $25^{\circ} \mathrm{N}$, moving from south to north from May to September, which substantially affects the synoptic conditions in China. Flat westerly wind at $500 \mathrm{hPa}$ prevails over the NCP and its surrounding regions, indicating a stable weather condition. The mean sea level pressure shows that most of areas in the NCP are continually influenced by the ASM and the high-pressure system centering in the western Pacific, causing the prevailing southeasterlysouthwesterly wind over the NCP and its surrounding areas. The detailed description of the synoptic conditions during the study episode can be found in the Supplement.

In the region controlled by the western Pacific subtropical high, a subsidence airflow is dominant, with calm or weak winds, and the temperature is extremely high due to the strong sunlight, which is favorable for the accumulation and formation of air pollutants. The air pollutants are likely to be transported from south to north under the persistent effect of southerly winds.

Figures 3 and 4 present the relationship of $\mathrm{PM}_{2.5}$ and $\mathrm{O}_{3}$ concentrations in the NCP with those in NEC and NWC during the ASM season from 2013 to 2016, respectively. The observed $\mathrm{PM}_{2.5}$ and $\mathrm{O}_{3}$ concentrations in the NCP exhibit a positive correlation with those in NEC and NWC, with the correlation coefficients generally exceeding 0.55 . There are two possible reasons for the positive correlation of $\mathrm{PM}_{2.5}$ and $\mathrm{O}_{3}$ concentrations between the NCP and its surrounding regions. One is that when the NCP and its neighboring areas are controlled by the same large-scale synoptic pattern, the concentrations of air pollutants generally vary synchronously. The other is the trans-boundary transport of air pollutants originated from the NCP to its surrounding areas due to the southerly wind associated with the ASM. The correlation coefficients of $\mathrm{PM}_{2.5}$ and $\mathrm{O}_{3}$ concentrations in the provinces of NEC with those in the NCP generally decrease from south to north, with coefficients of $0.69,0.56$, and 0.52 for $\mathrm{PM}_{2.5}$, and of $0.86,0.76$, and 0.76 for $\mathrm{O}_{3}$ in Liaoning, Jilin, and Heilongjiang, respectively. The decreasing trend of the correlation coefficients also exists from east to west in NWC, with coefficients of 0.69 and 0.62 for $\mathrm{PM}_{2.5}$, and 0.87 and 0.84 for $\mathrm{O}_{3}$ in Shanxi and Shaanxi, respectively. Hence, when severe air pollution occurs in the NCP in summer, the air quality in its adjacent provinces is likely to be deteriorated, possibly caused by the trans-boundary transport of air pollutants originated from the NCP.

It is worth noting that the intensity of ASM substantially influences the temporal variation and spatial distribution of air pollutants (Wu et al., 2016). The East Asia summer monsoon index proposed by Zhang et al. (2003) is defined as a difference of anomalous zonal wind between the $10^{\circ}-20^{\circ} \mathrm{N}$, $100^{\circ}-150^{\circ} \mathrm{E}$ and $25^{\circ}-35^{\circ} \mathrm{N}, 100^{\circ}-150^{\circ} \mathrm{E}$ regions at $850 \mathrm{hPa}$ during summer (June-August). A year of monsoon index greater than or equal to 2 is defined as a strong summer monsoon year, and a year of monsoon index less than or equal to -2 is defined as a weak summer monsoon year. The mon- 

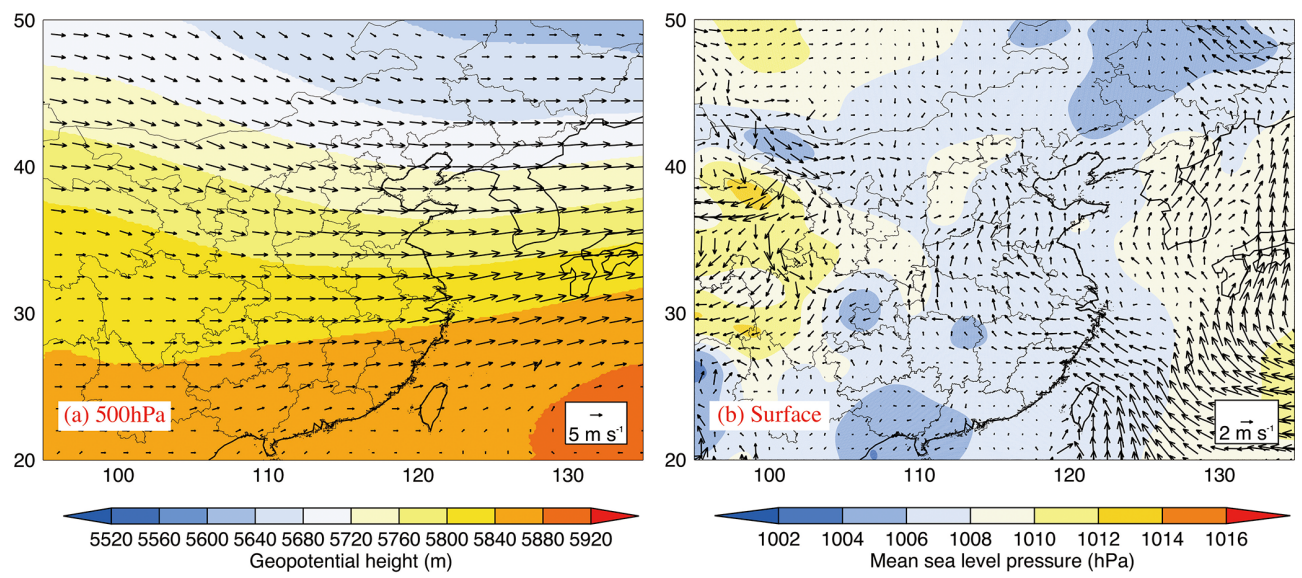

Figure 2. (a) Geopotential height at $500 \mathrm{hPa}$ and (b) the mean sea level pressure with wind vectors during the summer season in 2015 .
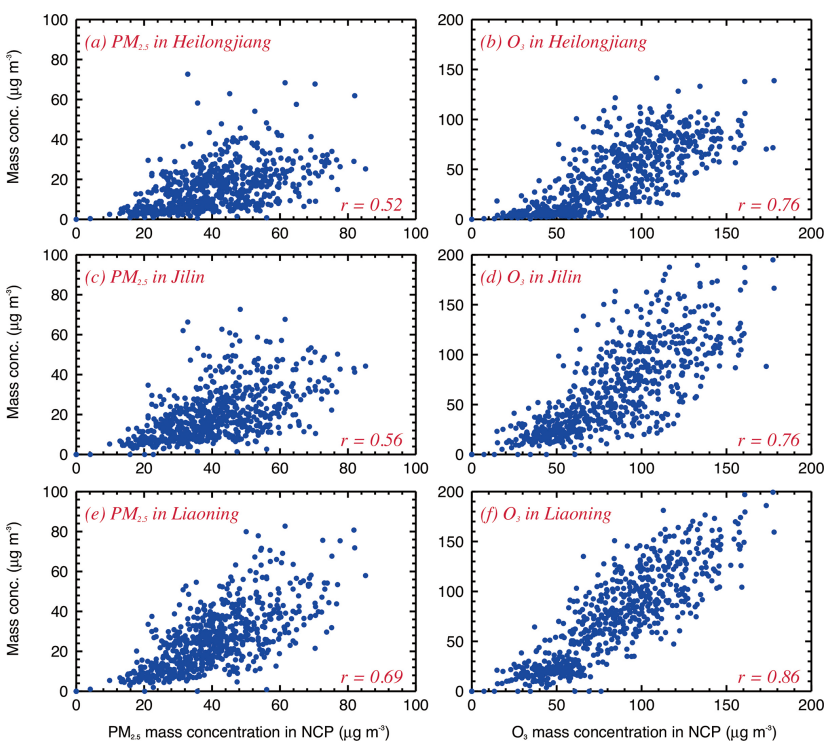

Figure 3. Relationships of observed $\mathrm{PM}_{2.5}$ and $\mathrm{O}_{3}$ concentrations in the NCP with those in NEC during May to September from 2013 to 2016.

soon index calculated by the China Meteorological Administration shows that the intensity of the summer monsoon in 2015 was close to the normal (Fig. S5).

\subsection{Model performance}

\subsection{1 $\mathrm{PM}_{2.5}, \mathrm{O}_{3}$ and $\mathrm{NO}_{2}$ simulations in northern China}

Figure 5 shows the temporal variations of observed and simulated near-surface $\mathrm{PM}_{2.5}, \mathrm{O}_{3}$, and $\mathrm{NO}_{2}$ concentrations averaged over monitoring sites in northern China. The WRFCHEM model generally simulates the diurnal variation of $\mathrm{PM}_{2.5}$ concentrations in northern China well, with an IOA of 0.91 . The model successfully reproduces the temporal vari-
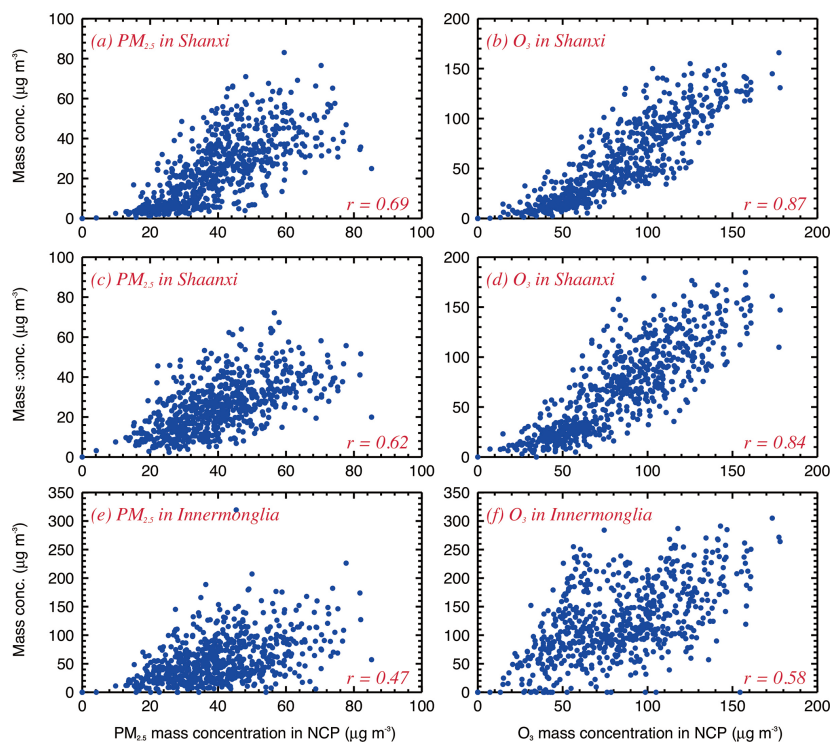

Figure 4. Same as Fig. 3, but for NWC.

ations of surface $\mathrm{O}_{3}$ concentrations compared with observations in northern China, e.g., peak $\mathrm{O}_{3}$ concentrations in the afternoon due to active photochemistry and low $\mathrm{O}_{3}$ concentrations during nighttime caused by $\mathrm{NO}_{x}$ titration, with an IOA of 0.98. However, the model underestimation still exists in simulating the $\mathrm{O}_{3}$ concentration, with an $\mathrm{MB}$ of $-4.0 \mu \mathrm{g} \mathrm{m}^{-3}$. The model also reasonably produces the $\mathrm{NO}_{2}$ diurnal profiles, but frequently overestimates the $\mathrm{NO}_{2}$ concentrations in the late evening due to the simulated low planetary boundary layer (PBL) height, and underestimates the concentration in the early morning because of the uncertainties in the $\mathrm{NO}_{x}$ emissions. The further analysis of the model performance of $\mathrm{PM}_{2.5}, \mathrm{O}_{3}$ and $\mathrm{NO}_{2}$ concentrations in northern China can be found in the Supplement. 

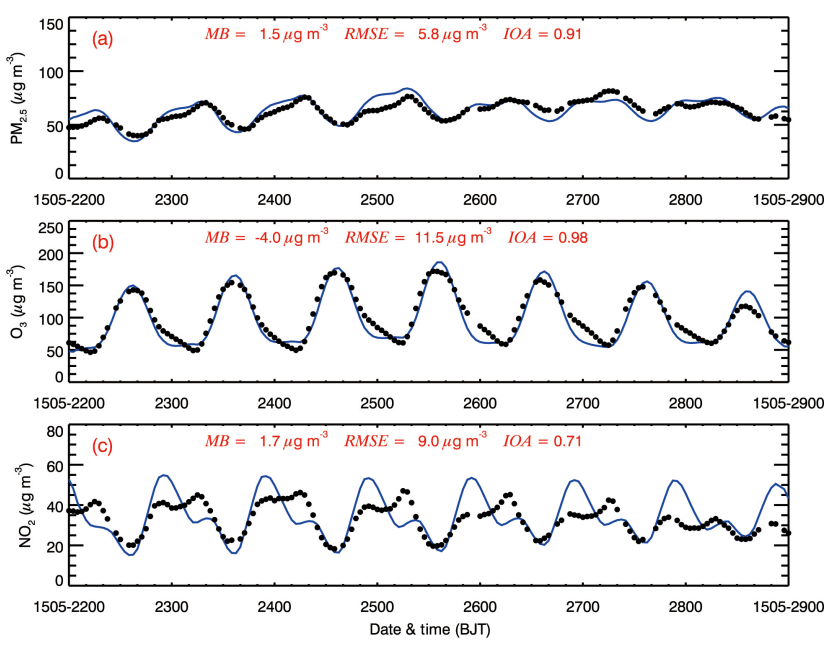

Figure 5. Comparison of measured (black dots) and predicted (blue line) diurnal profiles of near-surface hourly (a) $\mathrm{PM}_{2.5}$, (b) $\mathrm{O}_{3}$, and (c) $\mathrm{NO}_{2}$ averaged over all ambient monitoring stations in northern China from 22 to 28 May 2015.

\subsubsection{Aerosol species simulations in Beijing}

Figure 6 presents the temporal variations of simulated and observed aerosol species at the NCNST site in Beijing from 22 to 28 May 2015. Generally, the WRF-CHEM model predicts the temporal variations of the aerosol species against the measurements reasonably, especially for POA and nitrate aerosol, with IOAs of 0.81 and 0.90 , respectively. The model has difficulties in simulating the SOA concentrations well, with an IOA and MB of 0.69 and $-3.6 \mu \mathrm{g} \mathrm{m}^{-3}$, respectively. It is worth noting that many factors influence the SOA simulation, including measurements, meteorology, precursors emissions, and SOA formation mechanisms and treatments (Bei et al., 2012, 2013). The model reasonably tracks the temporal variation of the observed sulfate concentration, but the bias is still large, and the MB and IOA are $-1.2 \mu \mathrm{g} \mathrm{m}^{-3}$ and 0.68 , respectively. The sulfate source in the atmosphere is various, including $\mathrm{SO}_{2}$ gas-phase oxidation by hydroxyl radicals $(\mathrm{OH})$ and stabilized Criegee intermediates (sCI), aqueous reactions in cloud or fog droplets, and heterogeneous reactions on aerosol surfaces, as well as direct emissions from power plants and industries (G. Li et al., 2017a). G. Wang et al. (2016) have also reported that the aqueous oxidation of $\mathrm{SO}_{2}$ by $\mathrm{NO}_{2}$ is important for efficient sulfate formation. Considering that the model fails to resolve convective clouds well due to the $10 \mathrm{~km}$ horizontal resolution, the sulfate formation from the cloud process is generally underestimated. Additionally, a large amount of $\mathrm{SO}_{2}$ is emitted from point sources, such as power plants or agglomerated industrial zones, which is much more sensitive to wind field simulations (Bei et al., 2010). The model performs reasonably well in simulating the ammonium aerosol, with an IOA and $\mathrm{MB}$ of 0.77 and $-0.4 \mu \mathrm{g} \mathrm{m}^{-3}$, respectively.
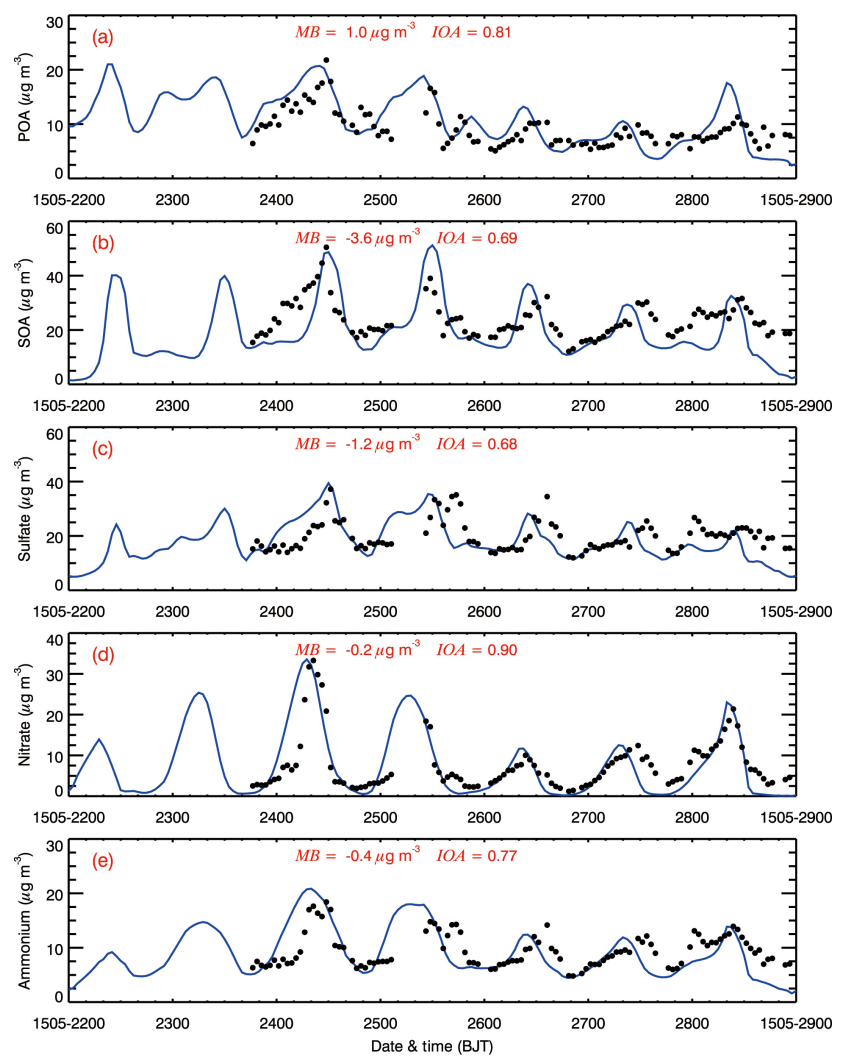

Figure 6. Comparison of measured (black dots) and simulated (black line) diurnal profiles of submicron aerosol species of (a) POA, (b) SOA, (c) sulfate, (d) nitrate, and (e) ammonium at the NCNST site in Beijing from 22 to 28 May 2015.

\subsubsection{Simulations of the spatial distribution of $\mathbf{P M}_{2.5}$ and $\mathrm{O}_{3}$ concentrations}

The peak $\mathrm{PM}_{2.5}$ concentration generally occurs from 08:00 to 10:00 Beijing Time (BJT) due to rush hour. Figure 7 provides the distributions of calculated and observed nearsurface $\mathrm{PM}_{2.5}$ concentrations along with the simulated wind fields at 08:00 BJT from 23 to 28 May 2015. The calculated $\mathrm{PM}_{2.5}$ spatial patterns generally agree well with the observations at the monitoring sites. The NCP experiences more severe $\mathrm{PM}_{2.5}$ pollution than its surrounding areas, with $\mathrm{PM}_{2.5}$ concentrations frequently exceeding $150 \mu \mathrm{g} \mathrm{m}^{-3}$ in the Beijing-Tianjin-Hebei region. During the study episodes, the pollutants are likely to be transported to NEC and NWC under the prevailing southwesterly or southeasterly winds in northern China, causing the $\mathrm{PM}_{2.5}$ concentrations in most areas of NEC and NWC to be frequently higher than $75 \mu \mathrm{g} \mathrm{m}^{-3}$.

The $\mathrm{O}_{3}$ concentration during summertime generally reaches its peak from 14:00 to 16:00 BJT in northern China (Fig. 5). Figure 8 shows the spatial distribution of calculated and measured near-surface $\mathrm{O}_{3}$ concentrations at 14:00 BJT from 23 to 28 May 2015, along with the simulated wind 

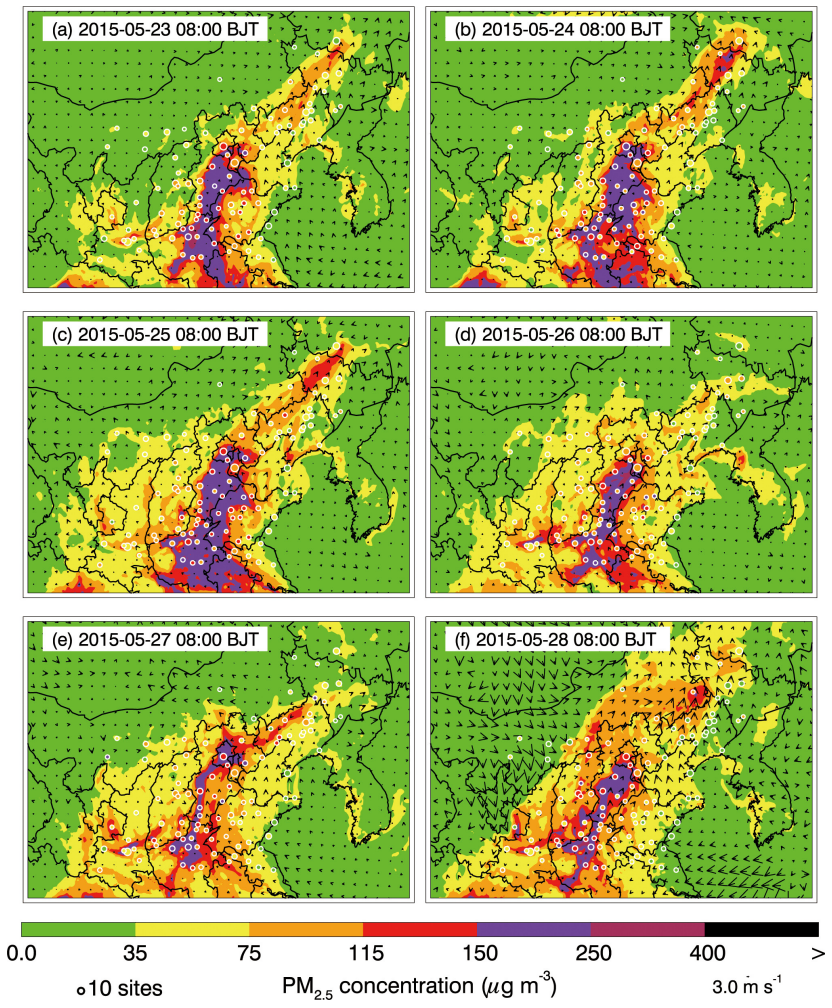

Figure 7. Pattern comparison of simulated vs. observed nearsurface $\mathrm{PM}_{2.5}$ at 08:00 BJT from 23 to 28 May 2015. Colored circles show $\mathrm{PM}_{2.5}$ observations, color contours show the $\mathrm{PM}_{2.5}$ simulations, and black arrows represent the simulated surface winds.

fields. Generally, the simulated $\mathrm{O}_{3}$ spatial patterns are consistent with the observations, but the model overestimation or underestimation still exists. The simulated high $\mathrm{O}_{3}$ concentrations at 14:00 BJT, exceeding $200 \mu \mathrm{g} \mathrm{m}^{-3}$, are frequently concentrated in the NCP, which is also consistent with the measurements. The $\mathrm{O}_{3}$ transport to NEC and NWC from the NCP is obvious when the winds are southeasterly or southwesterly, inducing severe $\mathrm{O}_{3}$ pollution in NEC and NWC.

In general, the simulated variations of $\mathrm{PM}_{2.5}, \mathrm{O}_{3}, \mathrm{NO}_{2}$, and aerosol species are in good agreement with observations, indicating that the simulations of meteorological conditions and chemical processes and the emission inventory used in the WRF-CHEM model are reasonable, providing a reliable basis for the further investigation.

\subsection{Effects of NCP emissions on the air quality in NEC and NWC}

To evaluate the contribution of NCP emissions to the air quality in its neighboring areas, four model simulations are performed, including $f_{\mathrm{NS}}$ with all anthropogenic emissions from the $\mathrm{NCP}$ and non-NCP areas, $f_{\mathrm{N}}$ with anthropogenic emissions from the NCP only, $f_{\mathrm{S}}$ with anthropogenic emissions from the non-NCP areas only, and $f_{0}$ without all an-
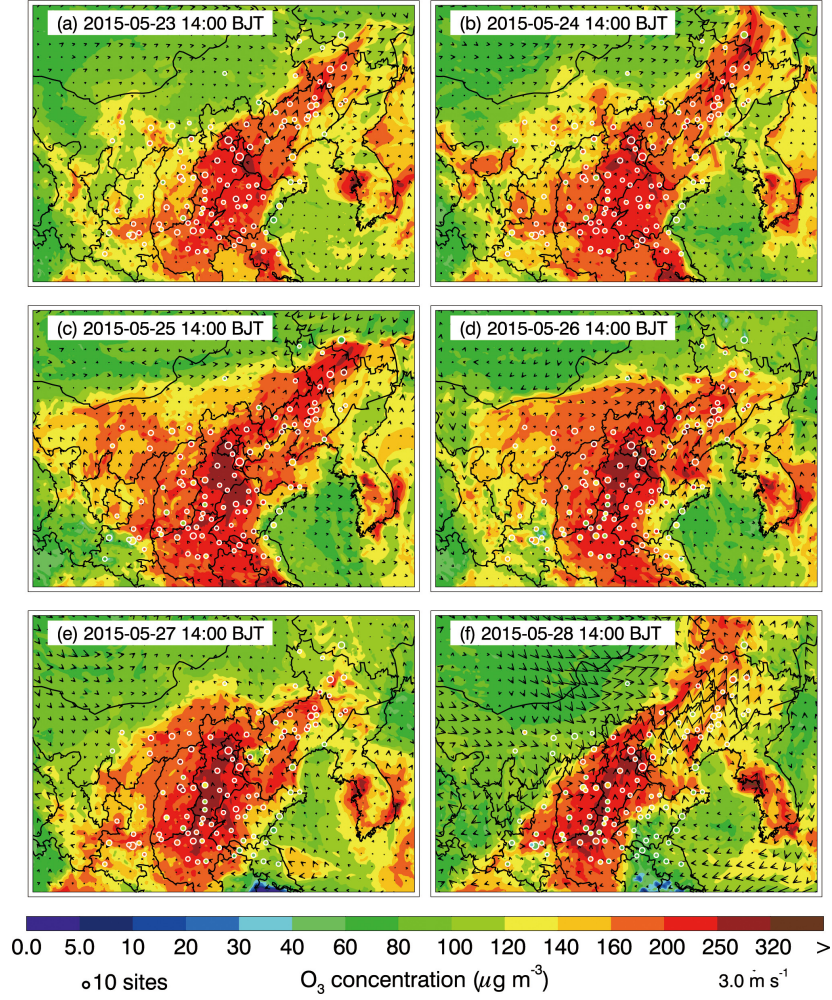

Figure 8. Same as Fig. 7, but for near-surface $\mathrm{O}_{3}$ at 14:00 BJT.

thropogenic emissions. Consequently, the air pollutant concentrations in NEC and NWC can be separated into four components, including contributions from the local emissions $\left(f_{\mathrm{S}}^{\prime}, f_{\mathrm{S}}-f_{0}\right)$, the trans-boundary transport of $\mathrm{NCP}$ emissions $\left(f_{\mathrm{N}}^{\prime}, f_{\mathrm{N}}-f_{0}\right)$, the interactions of these two emissions $\left(f_{\mathrm{NS}}^{\prime}, f_{\mathrm{NS}}-f_{\mathrm{N}}-f_{\mathrm{S}}+f_{0}\right)$, and the background $\left(f_{0}\right)$.

In the present study, the effect of NCP emissions on the $\mathrm{PM}_{2.5}$ and $\mathrm{O}_{3}$ concentrations in NEC and NWC is evaluated, considering that they have a long lifetime of several days in the troposphere and often constitute the primary air pollutant during summertime (Seinfeld and Pandis, 2006). However, the trans-boundary transport of $\mathrm{PM}_{10}$ is not considered due to its short lifetime of several hours, caused by the dry deposition and gravity, and the fact that $\mathrm{PM}_{10}$ is generally confined to its source region when the wind is not strong enough (Sun et al., 2006).

\subsubsection{Contributions of NCP emissions to $\mathrm{PM}_{2.5}$ levels in NEC and NWC}

Figure 9 shows the simulated spatial distribution of daily mean $\mathrm{PM}_{2.5}$ concentrations contributed by NCP emissions in NEC and NWC from 23 to 28 May 2015. The contribution of trans-boundary transport of NCP emissions to the $\mathrm{PM}_{2.5}$ concentration is remarkable in Liaoning, frequently exceeding $30 \mu \mathrm{g} \mathrm{m}^{-3}$ in most areas of the province during the episode. NCP emissions also considerably influence the $\mathrm{PM}_{2.5}$ con- 

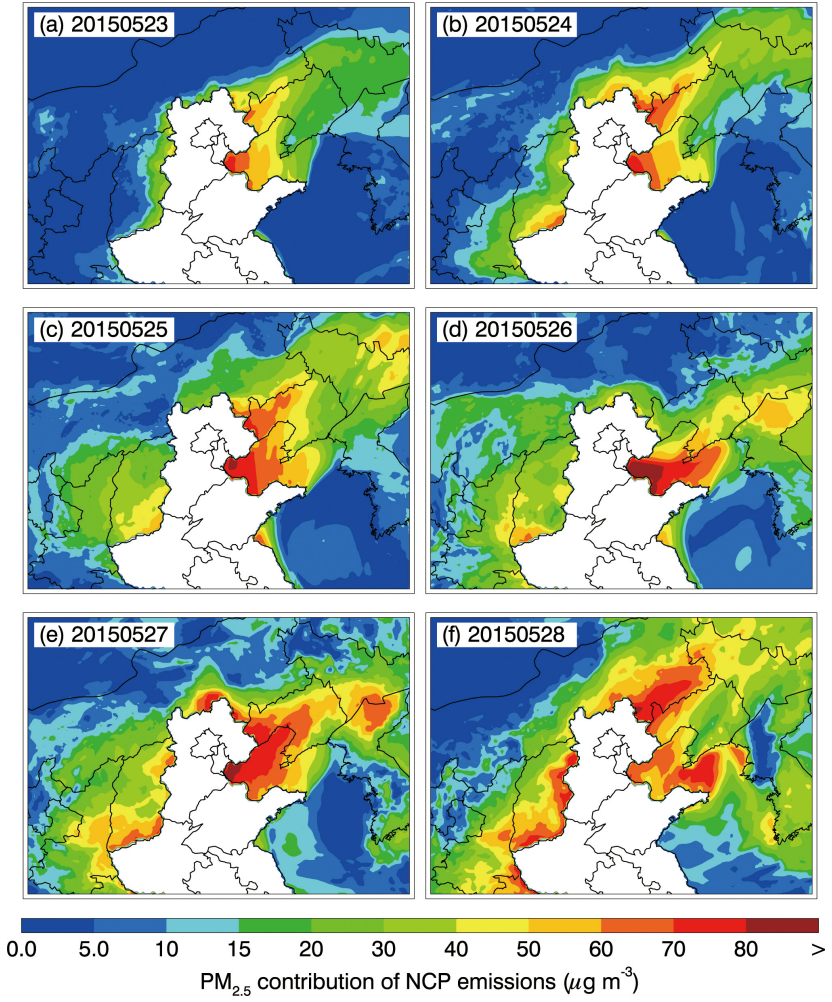

Figure 9. Contributions of NCP emissions to the daily mean near-surface $\mathrm{PM}_{2.5}$ concentration in NEC and NWC from 23 to 28 May 2015.

centration in Jilin, contributing $5-30 \mu \mathrm{g} \mathrm{m}^{-3}$ in most areas and occasionally exceeding $40 \mu \mathrm{g} \mathrm{m}^{-3}$. The effect of $\mathrm{NCP}$ emissions on the $\mathrm{PM}_{2.5}$ level in Shanxi and Shaanxi is increasingly evident from 23 to 28 May 2015, with the contribution of up to $50-60 \mu \mathrm{g} \mathrm{m}^{-3}$ in the southeast of Shanxi and to a lesser extent of $30-40 \mu \mathrm{g} \mathrm{m}^{-3}$ in the middle part of Shaanxi on 27-28 May. The contribution of trans-boundary transport of NCP emissions to the $\mathrm{PM}_{2.5}$ level in Inner Mongolia is not significant, which may be attributed to the location of the low pressure and terrain characteristics. Obviously, the effect of trans-boundary transport shows a stepwise characteristic: the closer to the NCP emission sources, the more remarkable the impact on the downwind areas. As a result, Liaoning and Shanxi provinces are substantially influenced by NCP emissions, while Jilin and Shaanxi provinces are affected to a lesser extent.

The impact of NCP emissions on the daily average $\mathrm{PM}_{2.5}$ concentration in NEC and NWC from 22 to 28 May 2015 is summarized in Table 2. On average, NCP emissions increase the $\mathrm{PM}_{2.5}$ concentrations by $24.2,9.6,13.9,6.5$, and $2.6 \mu \mathrm{g} \mathrm{m}^{-3}$ in Liaoning, Jilin, Shanxi, Shaanxi, and Inner Mongolia, with average percentage contributions of 40.6, 27.5, 32.2, 20.9, and $16.7 \%$, respectively. Figure 10 shows the episode-averaged $\mathrm{PM}_{2.5}$ percentage contribution from NCP emissions to the surrounding areas. The NCP emis-

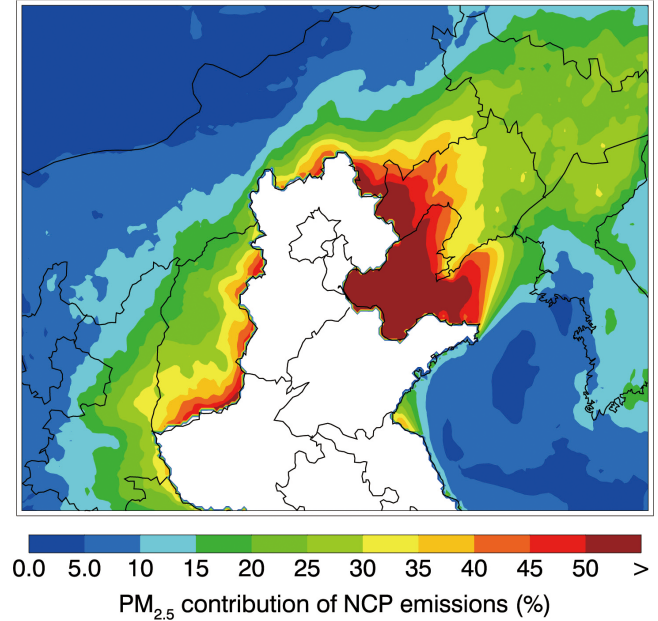

Figure 10. Average percentage contribution of NCP emissions to $\mathrm{PM}_{2.5}$ concentrations in NEC and NWC from 22 to 28 May 2015.

sions markedly affect the air quality in Liaoning, accounting for around $20-50 \%$ of the $\mathrm{PM}_{2.5}$ concentration during the episode and with the most substantial impact on the west part of the province. The NCP emissions contribute about $15-30 \%$ of the $\mathrm{PM}_{2.5}$ concentration in Jilin. Shanxi province is also remarkably affected by NCP emissions, with more than $25 \%$ of $\mathrm{PM}_{2.5}$ concentration contributed by NCP emissions in most areas. Although Shaanxi province is a little far from the NCP, NCP emissions still contribute about 10-35\% of the $\mathrm{PM}_{2.5}$ concentration. NCP emissions also enhance the $\mathrm{PM}_{2.5}$ concentration by 5-50\% in the southern edge of Inner Mongolia, which is adjacent to the NCP.

\subsubsection{Contributions of $\mathrm{NCP}$ emissions to $\mathrm{O}_{3}$ concentrations in NEC and NWC}

Figure 11 shows the simulated spatial distribution of the average afternoon $\mathrm{O}_{3}$ concentrations contributed by NCP emissions from 23 to 28 May 2015. Similar to the $\mathrm{PM}_{2.5}$ case, the contribution of NCP emissions to the $\mathrm{O}_{3}$ formation in Liaoning and Jilin province is increasingly enhanced during the episode (except on 26 May), and on 25 and 27 May, NCP emissions account for more than $70 \mu \mathrm{g} \mathrm{m}^{-3}$ of the $\mathrm{O}_{3}$ concentration in most areas of Liaoning. On 25 and 28 May, $\mathrm{NCP}$ emissions contribute more than $70 \mu \mathrm{g} \mathrm{m}^{-3}$ of the $\mathrm{O}_{3}$ concentration in some regions of Jilin. A lesser impact of NCP emissions on Jilin province on 26 May is due to the weakening of the low pressure. The NCP emissions play a progressively important role in $\mathrm{O}_{3}$ concentrations in Shanxi and Shaanxi provinces during the episode, especially on 27 and 28 May when the contribution can be up to $60 \mu \mathrm{g} \mathrm{m}^{-3}$. The impact of $\mathrm{NCP}$ emissions on $\mathrm{O}_{3}$ concentrations in Inner Mongolia is insignificant overall.

Table 3 summarizes the effects of NCP emissions on the average afternoon $\mathrm{O}_{3}$ concentration in NEC and NWC from 
Table 2. Daily average $\mathrm{PM}_{2.5}$ contributions $\left(\mu \mathrm{g} \mathrm{m}^{-3}\right)$ of NCP emissions in NEC and NWC from 22 to 28 May 2015.

\begin{tabular}{lrrrrr}
\hline Date & Jilin & Liaoning & Shanxi & Shaanxi & Inner Mongolia \\
\hline 22 & $0.7 \pm 0.4$ & $6.1 \pm 4.5$ & $0.7 \pm 1.1$ & $0.1 \pm 0.0$ & $0.2 \pm 0.1$ \\
23 & $6.1 \pm 2.1$ & $15.4 \pm 4.6$ & $4.7 \pm 5.5$ & $0.5 \pm 0.3$ & $1.0 \pm 0.5$ \\
24 & $10.0 \pm 2.1$ & $19.6 \pm 5.8$ & $12.7 \pm 5.0$ & $3.5 \pm 1.6$ & $2.2 \pm 1.3$ \\
25 & $14.4 \pm 4.4$ & $33.6 \pm 8.9$ & $14.6 \pm 5.1$ & $6.0 \pm 1.7$ & $2.6 \pm 1.8$ \\
26 & $6.4 \pm 2.8$ & $24.1 \pm 9.5$ & $16.3 \pm 5.7$ & $9.1 \pm 1.8$ & $1.9 \pm 0.8$ \\
27 & $11.4 \pm 3.6$ & $46.7 \pm 12.3$ & $20.7 \pm 7.3$ & $11.6 \pm 2.2$ & $3.2 \pm 1.9$ \\
28 & $18.0 \pm 7.4$ & $23.7 \pm 8.5$ & $27.5 \pm 9.0$ & $14.9 \pm 4.4$ & $6.9 \pm 3.4$ \\
\hline Average & & & & \\
$\left(\mu g\right.$ m $\left.^{-3}\right)$ & $9.6 \pm 3.3$ & $24.2 \pm 7.7$ & $13.9 \pm 5.5$ & $6.5 \pm 1.7$ & $2.6 \pm 1.4$ \\
\hline Average & & & & \\
$(\%)$ & $27.5 \pm 7.8$ & $40.6 \pm 9.7$ & $32.2 \pm 9.4$ & $20.9 \pm 4.1$ & $16.7 \pm 6.5$ \\
\hline
\end{tabular}

Table 3. Daily afternoon (12:00-18:00 BJT) average $\mathrm{O}_{3}$ contributions $\left(\mu \mathrm{g} \mathrm{m}^{-3}\right)$ of $\mathrm{NCP}$ emissions in NEC and NWC from 22 to 28 May 2015.

\begin{tabular}{lrrrrr}
\hline Date & Jilin & Liaoning & Shanxi & Shaanxi & Inner Mongolia \\
\hline 22 & $12.4 \pm 0.1$ & $23.9 \pm 2.7$ & $12.7 \pm 0.0$ & $7.7 \pm 0.0$ & $2.8 \pm 0.0$ \\
23 & $25.8 \pm 2.5$ & $38.9 \pm 6.2$ & $21.5 \pm 1.1$ & $13.1 \pm 0.3$ & $5.1 \pm 0.2$ \\
24 & $35.0 \pm 3.6$ & $47.5 \pm 8.1$ & $31.3 \pm 3.9$ & $21.2 \pm 1.9$ & $8.5 \pm 0.5$ \\
25 & $45.7 \pm 8.4$ & $69.5 \pm 15.5$ & $39.7 \pm 6.4$ & $21.5 \pm 2.5$ & $9.9 \pm 0.6$ \\
26 & $16.6 \pm 1.6$ & $41.0 \pm 5.9$ & $36.4 \pm 4.6$ & $21.7 \pm 2.4$ & $10.8 \pm 0.7$ \\
27 & $23.9 \pm 5.0$ & $69.3 \pm 16.4$ & $51.7 \pm 7.8$ & $33.5 \pm 4.5$ & $9.6 \pm 1.0$ \\
28 & $41.7 \pm 5.5$ & $35.1 \pm 6.5$ & $52.3 \pm 9.0$ & $26.5 \pm 4.7$ & $12.2 \pm 1.8$ \\
\hline Average & & & & & \\
$\left(\mu g \mathrm{~m}^{-3}\right)$ & $28.7 \pm 3.8$ & $46.5 \pm 8.8$ & $35.1 \pm 4.7$ & $20.7 \pm 2.3$ & $8.4 \pm 0.7$ \\
\hline Average & & & & \\
$(\%)$ & $19.5 \pm 2.9$ & $27.4 \pm 5.9$ & $21.2 \pm 3.2$ & $15.8 \pm 2.0$ & $8.0 \pm 0.7$ \\
\hline
\end{tabular}

22 to 28 May 2015. During the episode, NCP emissions substantially influence the $\mathrm{O}_{3}$ level in Liaoning province, and the afternoon $\mathrm{O}_{3}$ contribution is about $46.5 \mu \mathrm{g} \mathrm{m}^{-3}$ on average, ranging from 23.9 to $69.5 \mu \mathrm{g} \mathrm{m}^{-3}$. The NCP emissions also contribute an average of $28.7 \mu \mathrm{g} \mathrm{m}^{-3}$ to the $\mathrm{O}_{3}$ concentration in Jilin province, varying from 12.4 to $45.7 \mu \mathrm{g} \mathrm{m}^{-3}$. The contribution of NCP emissions to Shanxi and Shanxi provinces becomes increasingly significant during the episode, with an average of $35.1 \mathrm{~g} \mathrm{~m} \mathrm{~m}^{-3}$ for Shanxi province and $20.7 \mu \mathrm{g} \mathrm{m}^{-3}$ for Shaanxi province, respectively. The $\mathrm{O}_{3}$ concentration in Inner Mongolia is less influenced by NCP emissions, with an average of $8.4 \mu \mathrm{g} \mathrm{m}^{-3}$. Figure 12 illustrates the episodeaveraged afternoon $\mathrm{O}_{3}$ percentage contribution of NCP emissions to the surrounding areas. In NEC, NCP emissions account for $15-35 \%$ of the afternoon $\mathrm{O}_{3}$ concentration in most areas of Liaoning province and 10-30\% in Jilin province. In NWC, NCP emissions contribute $10-35 \%$ of the $\mathrm{O}_{3}$ concentration in Shanxi province and $10-25 \%$ in Shaanxi. In Inner Mongolia, the impact of NCP emissions on $\mathrm{O}_{3}$ formation is small, generally less than $15 \%$, except in the southern area adjacent to the NCP and Liaoning province, where a contribution of more than $10 \%$ is found. On average, NCP emissions distinctly increase the afternoon $\mathrm{O}_{3}$ concentrations in Liaoning, Jilin, Shanxi, Shaanxi, and Inner Mongolia, with average percentages of $27.4,19.5,21.2,15.8$, and $8.0 \%$, respectively (Table 3).

Additional sensitivity studies have also been performed to examine the potential influences of the cumulus parameterization on evaluation of the contribution of NCP emissions to the $\mathrm{PM}_{2.5}$ and $\mathrm{O}_{3}$ concentrations in NEC and $\mathrm{NWC}$, in which the cumulus parameterization is turned off. The difference of the contribution of NCP emissions to the $\mathrm{PM}_{2.5}$ and $\mathrm{O}_{3}$ concentrations in NEC and NWC is less than $0.8 \%$ between the simulations with and without the cumulus parameterization. Furthermore, it is worth noting that uncertainties from meteorological field simulations, emission inventories, and the chemical mechanism used in simulations have a large potential to influence the evaluation of the effect of NCP emissions on the $\mathrm{PM}_{2.5}$ and $\mathrm{O}_{3}$ concentrations in 

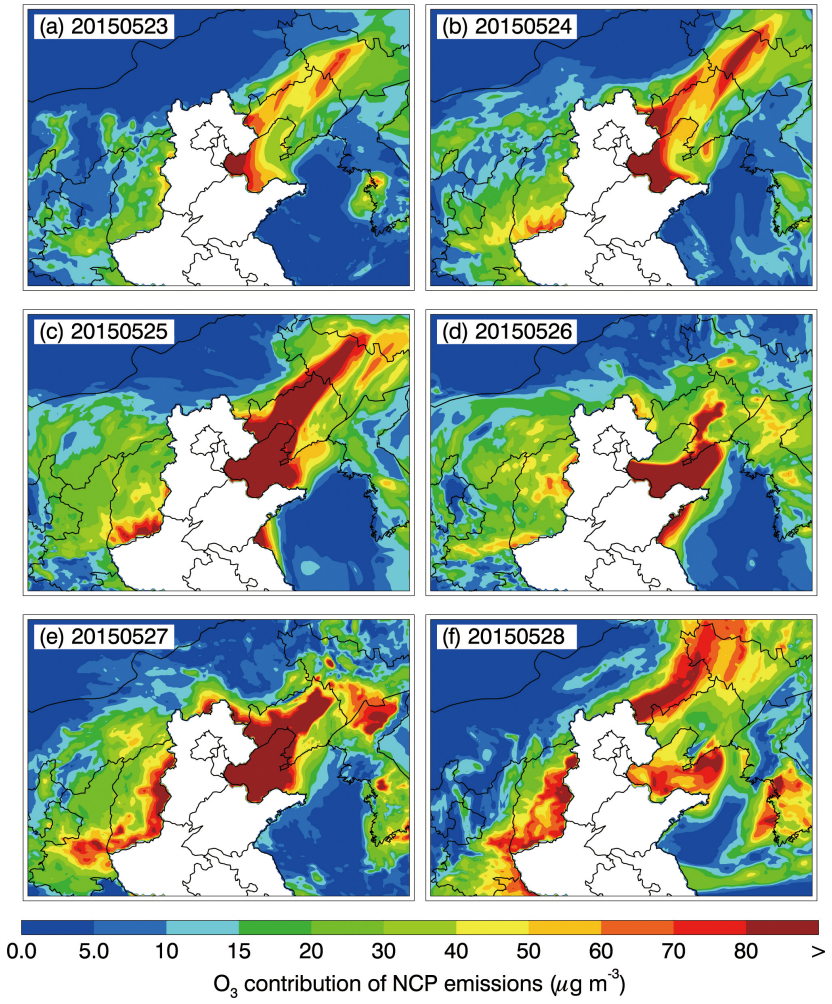

Figure 11. Same as Fig. 9, but for the afternoon (12:00-18:00 BJT) $\mathrm{O}_{3}$ concentration.

NEC and NWC (Carter and Atkinson, 1996; Lei et al., 2004; Song et al., 2010; Bei et al., 2017).

\section{Summary and conclusions}

Analyses of the synoptic pattern during the ASM season show that the southeasterly-southwesterly winds prevail in northern China, facilitating the trans-boundary transport of air pollutants from the NCP to NEC and NWC. The good relationships of $\mathrm{PM}_{2.5}$ and $\mathrm{O}_{3}$ concentrations in the NCP with those in NEC and NWC during the ASM season also indicate the possibility that the air quality in NEC and NWC is influenced by the trans-boundary transport of air pollutants originated from the NCP.

A widespread and severe pollution episode from 22 to 28 May 2015 in northern China is further simulated using the WRF-CHEM model to investigate the impact of the transboundary transport of NCP emissions on $\mathrm{PM}_{2.5}$ and $\mathrm{O}_{3}$ concentrations in NEC and NWC, when the region is affected by prevailing southeasterly-southwesterly winds associated with the ASM.

In general, the WRF-CHEM model reproduces the temporal variations and spatial distributions of $\mathrm{PM}_{2.5}, \mathrm{O}_{3}$, and $\mathrm{NO}_{2}$ concentrations well compared to observations in northern China, although the model biases still exist due to the un-

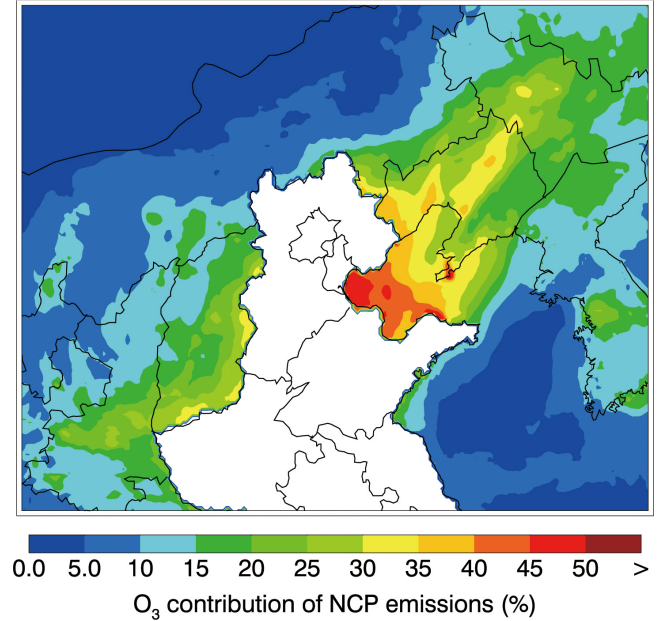

Figure 12. Same as Fig. 10, but for the afternoon (12:0018:00 BJT) $\mathrm{O}_{3}$ concentration.

certainties in simulated meteorological fields and the emission inventory. The model also performs reasonably well in simulating the variations of aerosol constituents against the ACSM measurement at the NCNST site in Beijing.

The FSA is used to investigate the contribution of transboundary transport of NCP emissions to $\mathrm{O}_{3}$ and $\mathrm{PM}_{2.5}$ levels in NEC and NWC. Model results show that NCP emissions contribute approximately an average of 24.2 and $13.9 \mu \mathrm{g} \mathrm{m}^{-3}$ to the $\mathrm{PM}_{2.5}$ concentration in Liaoning and Shanxi during the episode, with average percentage contributions of 40.6 and $32.2 \%$, respectively. The NCP emissions enhance the $\mathrm{PM}_{2.5}$ level by 9.6 and $6.5 \mu \mathrm{g} \mathrm{m}^{-3}$ in Jilin and Shaanxi on average, with percentage contributions of 27.5 and $20.9 \%$, respectively. The NCP emissions also substantially influence the $\mathrm{O}_{3}$ concentration in NEC and NWC. The NCP emissions increase the afternoon (12:00-18:00 BJT) $\mathrm{O}_{3}$ concentration in Liaoning by $46.5 \mu \mathrm{g} \mathrm{m}^{-3}$ on average during the episode, followed by $35.1 \mu \mathrm{g} \mathrm{m}^{-3}$ in Shanxi, $28.7 \mu \mathrm{g} \mathrm{m}^{-3}$ in Jilin, and $20.7 \mu \mathrm{g} \mathrm{m}^{-3}$ in Shaanxi, with average percentage contributions of $27.4,21.2,19.5$, and $15.8 \%$, respectively. In contrast, the contribution of the trans-boundary transport of NCP emissions to the $\mathrm{PM}_{2.5}$ and $\mathrm{O}_{3}$ concentration in Inner Mongolia is lower, with an average of 2.6 and $8.4 \mu \mathrm{g} \mathrm{m}^{-3}$, respectively. Our results demonstrate that when southerly winds are prevailing in northern China, air pollutants originated from the NCP are likely to be transported northwards and profoundly affect the air quality in NEC and NWC. Stringent control of NCP emissions not only mitigates local air pollution, but is also beneficial for the air quality in NEC and NWC during the ASM season.

It is worth noting that interactions between the air pollution in China and ASM are two-way and their relationships are complicated and interrelated, especially with regard to the aerosol-meteorology interaction. Aerosol impacts on meteorology are significant due to its direct and indirect ef- 
fects, which further influence the air pollution conditions in the lower troposphere. The aerosol semi-direct effect induced by the light-absorbing aerosols in the atmosphere stabilizes the PBL and thus reduces the PBL height to exacerbate the accumulation of air pollutants within the PBL, particularly for the aging process of black carbon which considerably enhances light absorption (Wang et al., 2013; Khalizov et al., 2009; Peng et al., 2016). In addition, aerosol plays an important role in the process of cloud formation and precipitation via acting as cloud condensation nuclei $(\mathrm{CCN})$ and ice nuclei (IC). Therefore, aerosol-cloud interactions modify temperature and moisture profiles and influence precipitation, leading to potential feedback on the atmospheric chemistry (Wang et al., 2011). In addition, the ASM substantially influences the spatial characteristics of the air pollutants' transport and distribution in eastern China on seasonal, interannual, and decadal scales (Wu et al., 2016). Further studies need to be performed to investigate the impacts of the ASM variation on the air pollutants' transport, which is modulated by climate changes.

Although the model performs well in simulating $\mathrm{PM}_{2.5}$, $\mathrm{O}_{3}$, and $\mathrm{NO}_{2}$ during the episode in northern China, the uncertainties from meteorological fields and the emission inventory still exist. Future studies need to be conducted to improve the WRF-CHEM model simulations and to further assess the contributions of the trans-boundary transport of NCP emissions under specific synoptic patterns, considering the rapid changes in anthropogenic emissions, which are not reflected in the present study. Therefore, more episode simulations during the ASM season should be performed to comprehensively evaluate the contribution of the trans-boundary transport of NCP emissions to the air quality in its downwind regions and support the design and implementation of effective emission control strategies.

Data availability. The real-time $\mathrm{O}_{3}$ and $\mathrm{PM}_{2.5}$ observations are accessible for the public on the following website: http://106.37.208. 233:20035/ (last access: 2 June 2018) (China MEP, 2013a). One can also access the historic profile of observed ambient pollutants by visiting http://www.aqistudy.cn/ (last access: 2 June 2018) (China MEP, 2013b).

Supplement. The supplement related to this article is available online at: https://doi.org/10.5194/acp-18-8491-2018-supplement.

Competing interests. The authors declare that they have no conflict of interest.

Special issue statement. This article is part of the special issue "Regional transport and transformation of air pollution in eastern China”. It is not associated with a conference.
Acknowledgements. This work is financially supported by the National Key R\&D Plan (Quantitative Relationship and Regulation Principle between Regional Oxidation Capacity of Atmospheric and Air Quality (2017YFC0210000)). Naifang Bei is supported by the National Natural Science Foundation of China (no. 41275101 and no. 41430424) and the Fundamental Research Funds for the Central Universities of China. Guohui Li is supported by the Hundred Talents Program of the Chinese Academy of Sciences and the National Natural Science Foundation of China (no. 41661144020).

Edited by: Luisa Molina

Reviewed by: two anonymous referees

\section{References}

Bei, N., Lei, W., Zavala, M., and Molina, L. T.: Ozone predictabilities due to meteorological uncertainties in the Mexico City basin using ensemble forecasts, Atmos. Chem. Phys., 10, 6295-6309, https://doi.org/10.5194/acp-10-6295-2010, 2010.

Bei, N., Li, G., and Molina, L. T.: Uncertainties in SOA simulations due to meteorological uncertainties in Mexico City during MILAGRO-2006 field campaign, Atmos. Chem. Phys., 12, 11295-11308, https://doi.org/10.5194/acp-12-11295-2012, 2012.

Bei, N. F., Li, G. H., Zavala, M., Barrera, H., Torres, R., Grutter, M., Gutierrez, W., Garcia, M., Ruiz-Suarez, L. G., Ortinez, A., Guitierrez, Y., Alvarado, C., Flores, I., and Molina, L. T.: Meteorological overview and plume transport patterns during Cal-Mex 2010, Atmos. Environ., 70, 477-489, https://doi.org/10.1016/j.atmosenv.2012.01.065, 2013.

Bei, N., Wu, J., Elser, M., Feng, T., Cao, J., El-Haddad, I., Li, X., Huang, R., Li, Z., Long, X., Xing, L., Zhao, S., Tie, X., Prévôt, A. S. H., and Li, G.: Impacts of meteorological uncertainties on the haze formation in Beijing-Tianjin-Hebei (BTH) during wintertime: a case study, Atmos. Chem. Phys., 17, 14579-14591, https://doi.org/10.5194/acp-17-14579-2017, 2017.

Cao, J. J., Lee, S. C., Chow, J. C., Watson, J. G., Ho, K. F., Zhang, R J., Jin, Z. D., Shen, Z. X., Chen, G. C., and Kang, Y. M.: Spatial and seasonal distributions of carbonaceous aerosols over China, J. Geophys. Res.-Atmos., 112, 22-11, 2007.

Cao, Z. Q., Sheng, L. F., Liu, Q., Yao, X. H., and Wang, W. C.: Interannual increase of regional haze-fog in North China Plain in summer by intensified easterly winds and orographic forcing, Atmos. Environ., 122, 154-162, https://doi.org/10.1016/j.atmosenv.2015.09.042, 2015.

Carter, W. P. L. and Atkinson, R.: Development and evaluation of a detailed mechanism for the atmospheric reactions of isoprene and $\mathrm{NO}_{x}$, Int. J. Chem. Kinet., 28, 497-530, 1996.

Chan, C. K. and Yao, X.: Air pollution in mega cities in China, Atmos. Environ., 42, 1-42, 2008.

Chen, F. and Dudhia, J.: Coupling an advanced land surfacehydrology model with the Penn State-NCAR MM5 modeling system. Part I: Model implementation and sensitivity, Mon. Weather Rev., 129, 569-585, https://doi.org/10.1175/15200493(2001)129<0569:caalsh>2.0.co;2, 2001.

Cheng, X. G., Zhao, T. L., Gong, S. L., Xu, X. D., Han, Y. X., Yin, Y., Tang, L. L., He, H. C., and He, J. H.: Implications of East Asian summer and winter monsoons for interannual aerosol vari- 
ations over central-eastern China, Atmos. Environ., 129, 218228, https://doi.org/10.1016/j.atmosenv.2016.01.037, 2016.

China MEP (Ministry of Environmental Protection, China): Air Quality Observation Real-time Release Platform of MEP Data Center, available at: http://106.37.208.233:20035/ (last access: 2 June 2018), 2013a.

China MEP (Ministry of Environmental Protection, China): Online Monitoring and Analysis Platform of China Air Quality, available at: http://www.aqistudy.cn/ (last access: 2 June 2018), 2013b.

Chou, M.-D. and Suarez, M. J.: A solar radiation parameterization for atmospheric studies, NASA Tech. Rep. NASA/TM-199910460, 15, 38 pp., 1999.

Chou, M.-D. and Suarez, M. J.: A thermal infrared radiation parameterization for atmospheric studies, NASA/TM-2001-104606, 19, 55 pp., 2001.

Ding, Y. H.: Summer monsoon rainfalls in china, J. Meteorol. Soc. Japan, 70, 373-396, 1992.

Ding, Y. H. and Chan, J. C. L.: The East Asian summer monsoon: an overview, Meteorol. Atmos. Phys., 89, 117-142, https://doi.org/10.1007/s00703-005-0125-z, 2005.

Feng, T., Bei, N., Huang, R.-J., Cao, J., Zhang, Q., Zhou, W., Tie, X., Liu, S., Zhang, T., Su, X., Lei, W., Molina, L. T., and $\mathrm{Li}, \mathrm{G}$.: Summertime ozone formation in Xi' an and surrounding areas, China, Atmos. Chem. Phys., 16, 4323-4342, https://doi.org/10.5194/acp-16-4323-2016, 2016.

Gabusi, V., Pisoni, E., and Volta, M.: Factor separation in air quality simulations, Ecol. Modell., 218, 383-392, https://doi.org/10.1016/j.ecolmodel.2008.07.030, 2008.

Gao, Y., Liu, X., Zhao, C., and Zhang, M.: Emission controls versus meteorological conditions in determining aerosol concentrations in Beijing during the 2008 Olympic Games, Atmos. Chem. Phys., 11, 12437-12451, https://doi.org/10.5194/acp-11-124372011, 2011.

Guenther, A., Karl, T., Harley, P., Wiedinmyer, C., Palmer, P. I., and Geron, C.: Estimates of global terrestrial isoprene emissions using MEGAN (Model of Emissions of Gases and Aerosols from Nature), Atmos. Chem. Phys., 6, 3181-3210, https://doi.org/10.5194/acp-6-3181-2006, 2006.

Guo, S., Hu, M., Zamora, M. L., Peng, J. F., Shang, D. J., Zheng, J., Du, Z. F., Wu, Z., Shao, M., Zeng, L. M., Molina, M. J., and Zhang, R. Y.: Elucidating severe urban haze formation in China, P. Natl. Acad. Sci. USA, 111, 17373-17378, https://doi.org/10.1073/pnas.1419604111, 2014.

Han, J. S., Moon, K. J., Lee, S. J., Kim, Y. J., Ryu, S. Y., Cliff, S. S., and Yi, S. M.: Size-resolved source apportionment of ambient particles by positive matrix factorization at Gosan background site in East Asia, Atmos. Chem. Phys., 6, 211-223, https://doi.org/10.5194/acp-6-211-2006, 2006.

He, K., Yang, F., Ma, Y., Zhang, Q., Yao, X., Chan, C. K., Cadle, S., Chan, T., and Mulawa, P.: The characteristics of $\mathrm{PM}_{2.5}$ in Beijing, China, Atmos. Environ., 35, 4959-4970, 2001.

Hong, S.-Y. and Lim, J.-O. J.: The WRF Single-Moment 6-Class Microphysics Scheme (WSM6), Asia-Pacific J. Atmos. Sci., 42, 129-151, 2006.

Horowitz, L. W., Walters, S., Mauzerall, D. L., Emmons, L. K., Rasch, P. J., Granier, C., Tie, X. X., Lamarque, J. F., Schultz, M. G., Tyndall, G. S., Orlando, J. J., and Brasseur, G. P.: A global simulation of tropospheric ozone and related tracers: Description and evaluation of MOZART, version 2, J. Geophys. Res.-Atmos., 108, 4784, https://doi.org/10.1029/2002jd002853, 2003.

Hu, J. L., Wang, Y. G., Ying, Q., and Zhang, H. L.: Spatial and temporal variability of $\mathrm{PM}_{2.5}$ and PM10 over the North China Plain and the Yangtze River Delta, China, Atmos. Environ., 95, 598-609, https://doi.org/10.1016/j.atmosenv.2014.07.019, 2014.

Huang, J., Liu, H., Crawford, J. H., Chan, C., Considine, D. B., Zhang, Y., Zheng, X., Zhao, C., Thouret, V., Oltmans, S. J., Liu, S. C., Jones, D. B. A., Steenrod, S. D., and Damon, M. R.: Origin of springtime ozone enhancements in the lower troposphere over Beijing: in situ measurements and model analysis, Atmos. Chem. Phys., 15, 5161-5179, https://doi.org/10.5194/acp15-5161-2015, 2015.

Janjić, Z. I.: Nonsingular Implementation of the Mellor - Yamada Level 2.5 Scheme in the NCEP Meso Model, Ncep Office Note, 436, 2002.

Kain, J. S.: The Kain Fritsch Convective Parameterization: An Update, J. Appl. Meteorol., 43, 170-181, 2004.

Kang, I. S., Jin, K., Wang, B., Lau, K. M., Shukla, J., Krishnamurthy, V., Schubert, S. D., Wailser, D. E., Stern, W. F., Kitoh, A., Meehl, G. A., Kanamitsu, M., Galin, V. Y., Satyan, V., Park, C. K., and Liu, Y.: Intercomparison of the climatological variations of Asian summer monsoon precipitation simulated by 10 GCMs, Clim. Dynam., 19, 383-395, https://doi.org/10.1007/s00382-002-0245-9, 2002.

Khalizov, A. F., Xue, H. X., Wang, L., Zheng, J., and Zhang, R. Y.: Enhanced Light Absorption and Scattering by Carbon Soot Aerosol Internally Mixed with Sulfuric Acid, J. Phys. Chem. A, 113, 1066-1074, https://doi.org/10.1021/jp807531n, 2009.

Kulmala, M., Laaksonen, A., and Pirjola, L.: Parameterizations for sulfuric acid/water nucleation rates, J. Geophys. Res., 103, 83018307, 1998.

Kurokawa, J., Ohara, T., Morikawa, T., Hanayama, S., JanssensMaenhout, G., Fukui, T., Kawashima, K., and Akimoto, H.: Emissions of air pollutants and greenhouse gases over Asian regions during 2000-2008: Regional Emission inventory in ASia (REAS) version 2, Atmos. Chem. Phys., 13, 11019-11058, https://doi.org/10.5194/acp-13-11019-2013, 2013.

Lau, K. M.: East-asian summer monsoon rainfall variability and climate teleconnection, J. Meteorol. Soc. Japan, 70, 211-242, 1992.

Lau, K. M., Yang, G. J., and Shen, S. H.: Seasonal and intraseasonal climatology of summer monsoon rainfall over East-Asia, Mon. Weather Rev., 116, 18-37, https://doi.org/10.1175/15200493(1988)116<0018:saicos>2.0.co;2, 1988.

Lei, W., Zhang, R., Tie, X., and Hess, P.: Chemical characterization of ozone formation in the Houston-Galveston area: A chemical transport model study, J. Geophys. Res.-Atmos., 109, D12301, https://doi.org/10.1029/2003JD004219, 2004.

Li, G., Lei, W., Zavala, M., Volkamer, R., Dusanter, S., Stevens, P., and Molina, L. T.: Impacts of HONO sources on the photochemistry in Mexico City during the MCMA2006/MILAGO Campaign, Atmos. Chem. Phys., 10, 6551-6567, https://doi.org/10.5194/acp-10-6551-2010, 2010.

Li, G., Bei, N., Tie, X., and Molina, L. T.: Aerosol effects on the photochemistry in Mexico City during MCMA2006/MILAGRO campaign, Atmos. Chem. Phys., 11, 51695182, https://doi.org/10.5194/acp-11-5169-2011, $2011 \mathrm{a}$.

Li, G., Zavala, M., Lei, W., Tsimpidi, A. P., Karydis, V. A., Pandis, S. N., Canagaratna, M. R., and Molina, L. 
T.: Simulations of organic aerosol concentrations in Mexico City using the WRF-CHEM model during the MCMA2006/MILAGRO campaign, Atmos. Chem. Phys., 11, 37893809, https://doi.org/10.5194/acp-11-3789-2011, 2011b.

Li, G., Lei, W., Bei, N., and Molina, L. T.: Contribution of garbage burning to chloride and $\mathrm{PM}_{2.5}$ in Mexico City, Atmos. Chem. Phys., 12, 8751-8761, https://doi.org/10.5194/acp12-8751-2012, 2012.

Li, G. H., Bei, N. F., Zavala, M., and Molina, L. T.: Ozone formation along the California Mexican border region during Cal-Mex 2010 field campaign, Atmos. Environ., 88, 370-389, https://doi.org/10.1016/j.atmosenv.2013.11.067, 2014.

Li, G., Bei, N., Cao, J., Huang, R., Wu, J., Feng, T., Wang, Y., Liu, S., Zhang, Q., Tie, X., and Molina, L. T.: A possible pathway for rapid growth of sulfate during haze days in China, Atmos. Chem. Phys., 17, 3301-3316, https://doi.org/10.5194/acp17-3301-2017, 2017a.

Li, G., Bei, N., Cao, J., Wu, J., Long, X., Feng, T., Dai, W., Liu, S., Zhang, Q., and Tie, X.: Widespread and persistent ozone pollution in eastern China during the non-winter season of 2015: observations and source attributions, Atmos. Chem. Phys., 17, 2759-2774, https://doi.org/10.5194/acp-17-2759-2017, 2017b.

Li, H., Zhang, Q., Zhang, Q., Chen, C., Wang, L., Wei, Z., Zhou, S., Parworth, C., Zheng, B., Canonaco, F., Prévôt, A. S. H., Chen, P., Zhang, H., Wallington, T. J., and He, K.: Wintertime aerosol chemistry and haze evolution in an extremely polluted city of the North China Plain: significant contribution from coal and biomass combustion, Atmos. Chem. Phys., 17, 4751-4768, https://doi.org/10.5194/acp-17-4751-2017, 2017.

Li, J., Xie, S. D., Zeng, L. M., Li, L. Y., Li, Y. Q., and Wu, R. R.: Characterization of ambient volatile organic compounds and their sources in Beijing, before, during, and after Asia-Pacific Economic Cooperation China 2014, Atmos. Chem. Phys., 15, 7945-7959, https://doi.org/10.5194/acp-15-7945-2015, 2015.

Li, Z. Q., Lau, W. K. M., Ramanathan, V., Wu, G., Ding, Y., Manoj, M. G., Liu, J., Qian, Y., Li, J., Zhou, T., Fan, J., Rosenfeld, D., Ming, Y., Wang, Y., Huang, J., Wang, B., Xu, X., Lee, S. S., Cribb, M., Zhang, F., Yang, X., Zhao, C., Takemura, T., Wang, K., Xia, X., Yin, Y., Zhang, H., Guo, J., Zhai, P. M., Sugimoto, N., Babu, S. S., and Brasseur, G. P.: Aerosol and monsoon climate interactions over Asia, Rev. Geophys., 54, 866-929, https://doi.org/10.1002/2015rg000500, 2016.

Liu, Z., Wang, Y., Gu, D., Zhao, C., Huey, L. G., Stickel, R., Liao, J., Shao, M., Zhu, T., Zeng, L., Amoroso, A., Costabile, F., Chang, C.-C., and Liu, S.-C.: Summertime photochemistry during CAREBeijing-2007: $\mathrm{RO}_{x}$ budgets and $\mathrm{O}_{3}$ formation, Atmos. Chem. Phys., 12, 7737-7752, https://doi.org/10.5194/acp12-7737-2012, 2012.

Long, X., Tie, X., Cao, J., Huang, R., Feng, T., Li, N., Zhao, S., Tian, J., Li, G., and Zhang, Q.: Impact of crop field burning and mountains on heavy haze in the North China Plain: a case study, Atmos. Chem. Phys., 16, 9675-9691, https://doi.org/10.5194/acp-16-9675-2016, 2016.

Ma, Z., Xu, J., Quan, W., Zhang, Z., Lin, W., and Xu, $X .:$ Significant increase of surface ozone at a rural site, north of eastern China, Atmos. Chem. Phys., 16, 3969-3977, https://doi.org/10.5194/acp-16-3969-2016, 2016.

Nenes, A., Pandis, S. N., and Pilinis, C.: ISORROPIA: A new thermodynamic equilibrium model for multiphase multi- component inorganic aerosols, Aqua. Geochem., 4, 123-152, https://doi.org/10.1023/a:1009604003981, 1998.

Parrish, D. D. and Zhu, T.: Clean Air for Megacities, Science, 326, 674-675, https://doi.org/10.1126/science.1176064, 2009.

Peng, J. F., Hu, M., Guo, S., Du, Z. F., Zheng, J., Shang, D. J., Zamora, M. L., Zeng, L. M., Shao, M., Wu, Y. S., Zheng, J., Wang, Y., Glen, C. R., Collins, D. R., Molina, M. J., and Zhang, R. Y.: Markedly enhanced absorption and direct radiative forcing of black carbon under polluted urban environments, P. Natl. Acad. Sci. USA, 113, 4266-4271, https://doi.org/10.1073/pnas.1602310113, 2016.

Pu, W. W., Zhao, X. J., Shi, X. F., Ma, Z. Q., Zhang, X. L., and Yu, B.: Impact of long-range transport on aerosol properties at a regional background station in Northern China, Atmos. Res., 153, 489-499, https://doi.org/10.1016/j.atmosres.2014.10.010, 2015.

Qiu, C. and Zhang, R. Y.: Multiphase chemistry of atmospheric amines, Phys. Chem. Chem. Phys., 15, 5738-5752, https://doi.org/10.1039/c3cp43446j, 2013.

Seinfeld, J. H. and Pandis, S. N.: Atmospheric Chemistry and Physics: From Air Pollution to Climate Change, 2nd Edn., John Wiley \& Sons Inc., New York, 2006.

Song, J., Lei, W., Bei, N., Zavala, M., de Foy, B., Volkamer, R., Cardenas, B., Zheng, J., Zhang, R., and Molina, L. T.: Ozone response to emission changes: a modeling study during the MCMA-2006/MILAGRO Campaign, Atmos. Chem. Phys., 10, 3827-3846, https://doi.org/10.5194/acp-10-3827-2010, 2010.

Stein, U. and Alpert, P.: Factor separation in numerical simulations, J. Atmos. Sci., 50, 2107-2115, https://doi.org/10.1175/15200469(1993)050<2107:fsins>2.0.co;2, 1993.

Sun, Y. L., Zhuang, G. S., Tang, A. H., Wang, Y., and An, Z. S.: Chemical characteristics of $\mathrm{PM}_{2.5}$ and $\mathrm{PM}_{10}$ in haze-fog episodes in Beijing, Environ. Sci. Technology, 40, 3148-3155, https://doi.org/10.1021/es051533g, 2006.

Sun, Y., Jiang, Q., Xu, Y., Ma, Y., Zhang, Y., Liu, X., Li, W., Wang, F., Li, J., and Wang, P.: Aerosol characterization over the North China Plain: Haze life cycle and biomass burning impacts in summer, J. Geophys. Res.-Atmos., 121, 2508-2521, https://doi.org/10.1002/2015JD024261, 2016.

Tang, G., Wang, Y., Li, X., Ji, D., Hsu, S., and Gao, X.: Spatialtemporal variations in surface ozone in Northern China as observed during 2009-2010 and possible implications for future air quality control strategies, Atmos. Chem. Phys., 12, 2757-2776, https://doi.org/10.5194/acp-12-2757-2012, 2012.

Wang, G., Zhang, R., Gomez, M. E., Yang, L., Zamora, M. L., Hu, M., Lin, Y., Peng, J., Guo, S., and Meng, J.: Persistent sulfate formation from London Fog to Chinese haze, P. Natl. Acad. Sci. USA, 113, 13630-13635, 2016.

Wang, Y., Wan, Q., Meng, W., Liao, F., Tan, H., and Zhang, R.: Long-term impacts of aerosols on precipitation and lightning over the Pearl River Delta megacity area in China, Atmos. Chem. Phys., 11, 12421-12436, https://doi.org/10.5194/acp-11-124212011, 2011.

Wang, Y., Khalizov, A., Levy, M., and Zhang, R. Y.: New Directions: Light absorbing aerosols and their atmospheric impacts, Atmos. Environ., 81, 713-715, https://doi.org/10.1016/j.atmosenv.2013.09.034, 2013.

Wang, Z. S., Zhang, D. W., Li, Y. T., Dong, X., Sun, R. W., and Sun, N. D.: Different air pollution situations of $\mathrm{O}_{3}$ and 
$\mathrm{PM}_{2.5}$ during summer in Beijing, Environ. Sci., 37, 807-815, https://doi.org/10.13227/j.hjkx.2016.03.004, 2016.

Weinhold, B.: Ozone nation - EPA standard panned by the people, Environmental Health Perspectives, 116, A302-A305, 2008.

Wu, G. X., Li, Z. Q., Fu, C. B., Zhang, X. Y., Zhang, R. Y., Zhang, R. H., Zhou, T. J., Li, J. P., Li, J. D., Zhou, D. G., Wu, L., Zhou, L. T., He, B., and Huang, R. H.: Advances in studying interactions between aerosols and monsoon in China, Sci. China-Earth Sci., 59, 1-16, https://doi.org/10.1007/s11430-015-5198-z, 2016.

Wu, J., Li, G., Cao, J., Bei, N., Wang, Y., Feng, T., Huang, R., Liu, S., Zhang, Q., and Tie, X.: Contributions of trans-boundary transport to summertime air quality in Beijing, China, Atmos. Chem. Phys., 17, 2035-2051, https://doi.org/10.5194/acp-172035-2017, 2017.

Xu, J., Zhang, X. L., Xu, X. F., Zhao, X. J., Meng, W., and Pu, W. W.: Measurement of surface ozone and its precursors in urban and rural sites in Beijing, in: Second International Conference on Mining Engineering and Metallurgical Technology, edited by: Zhu, R., Procedia Earth and Plantetary Science, Elsevier Science Bv, Amsterdam, 255-261, 2011.

Zhang, L., Liao, H., and Li, J. P.: Impacts of Asian summer monsoon on seasonal and interannual variations of aerosols over eastern China, J. Geophys. Res.-Atmos., 115, D00k05, https://doi.org/10.1029/2009jd012299, 2010.

Zhang, Q. Y., Tao, S. Y., and Chen, L. T.: The inter-annual variability of East Asian summer monsoon indices and its association with the pattern of general circulation over East Asia (in Chinese), Acta Meteorol. Sin., 61, 559-568, 2003.

Zhang, Q., Streets, D. G., Carmichael, G. R., He, K. B., Huo, H., Kannari, A., Klimont, Z., Park, I. S., Reddy, S., Fu, J. S., Chen, D., Duan, L., Lei, Y., Wang, L. T., and Yao, Z. L.: Asian emissions in 2006 for the NASA INTEX-B mission, Atmos. Chem. Phys., 9, 5131-5153, https://doi.org/10.5194/acp-9-5131-2009, 2009.

Zhang, R., Khalizova, A. F., Wang, L., Hu, M., and Xu, W.: Nucleation and growth of nanoparticles in the atmosphere, Chem. Rev., 112, 1957-2011, 2012.
Zhang, R., Jing, J., Tao, J., Hsu, S.-C., Wang, G., Cao, J., Lee, C. S. L., Zhu, L., Chen, Z., Zhao, Y., and Shen, Z.: Chemical characterization and source apportionment of $\mathrm{PM}_{2.5}$ in Beijing: seasonal perspective, Atmos. Chem. Phys., 13, 7053-7074, https://doi.org/10.5194/acp-13-7053-2013, 2013.

Zhang, R. Y., Wang, G. H., Guo, S., Zarnora, M. L., Ying, Q., Lin, Y., Wang, W. G., Hu, M., and Wang, Y.: Formation of Urban Fine Particulate Matter, Chem. Rev., 115, 3803-3855, 10.1021/acs.chemrev.5b00067, 2015.

Zhao, C., Wang, Y. H., Yang, Q., Fu, R., Cunnold, D., and Choi, Y.: Impact of East Asian summer monsoon on the air quality over China: View from space, J. Geophys. Res.-Atmos., 115, D09301, https://doi.org/10.1029/2009jd012745, 2010.

Zhao, J., Levitt, N. P., Zhang, R. Y., and Chen, J. M.: Heterogeneous reactions of methylglyoxal in acidic media: implications for secondary organic aerosol formation, Environ. Sci. Technol., 40, 7682-7687, 2006.

Zhao, X. J., Zhao, P. S., Xu, J., Meng,, W., Pu, W. W., Dong, F., He, D., and Shi, Q. F.: Analysis of a winter regional haze event and its formation mechanism in the North China Plain, Atmos. Chem. Phys., 13, 5685-5696, https://doi.org/10.5194/acp13-5685-2013, 2013.

Zhu, B., Akimoto, H., Wang, Z., Sudo, K., Tang, J., and Uno, I.: Why does surface ozone peak in summertime at Waliguan?, Geophys. Res. Lett., 31, L17104, https://doi.org/10.1029/2004gl020609, 2004.

Zhu, J. L., Liao, H., and Li, J. P.: Increases in aerosol concentrations over eastern China due to the decadal-scale weakening of the East Asian summer monsoon, Geophys. Res. Lett., 39, L09809, https://doi.org/10.1029/2012gl051428, 2012.

Zhuang, X. L., Wang, Y. S., He, H., Liu, J. G., Wang, X. M., Zhu, T. Y., Ge, M. F., Zhou, J., Tang, G. Q., and Ma, J. Z.: Haze insights and mitigation in China: An overview, J. Environ. Sci., 26, 2-12, https://doi.org/10.1016/s1001-0742(13)60376-9, 2014. 